\title{
PERBEDAAN KUALITAS KOMPOS SAMPAH ORGANIK MENGGUNAKAN EFFECTIVE MICROORGANISM 4 (EM4) DAN LARVA BLACK SOLDIER FLY DI DESA BUDUK TAHUN 2020
}

\author{
Dwi Lestari $^{1}$, I Nyoman Gede Suyasa ${ }^{2}$
}

\begin{abstract}
Composting is an effort in managing organic waste that can be done with the help of microorganisms to accelerate the composting process. One way is to use EM4 and Black Soldier Fly larvae. The purpose of this study was to analyze the differences in the quality of EM4 compost and Black Soldier Fly compost. Type of research used is pre-experimental design with one-shot case study design and use test independent $t$ test to analyze differences in the quality of compost. The samples used are 8 of Black Soldier Fly compost samples and eight secondary data of EM4 compost that have been tested before. The results showed that the average $N, P, K$ content in EM4 compost was $\mathrm{N}(1,7250 \%) ; \mathrm{P}_{2} \mathrm{O}_{5}(0,6975 \%) ; \mathrm{K}_{2} \mathrm{O}(0,9338 \%)$ while the average content of $N, P, K$ in compost Black Soldier Fly is $N$ (1.6625\%); $\mathrm{P}_{2} \mathrm{O}_{5}(0.9988 \%) ; \mathrm{K}_{2} \mathrm{O}(3.5038 \%)$ with the result of statistical test using independent t test show that there are differences in the value of potassium while the value of nitrogen and phosphorus has no difference.
\end{abstract}

Keywords: compost, EM4, Black Soldier Fly

PENDAHULUAN

Pengelolaan sampah masih menjadi salah satu masalah baik di negara maju maupun di negara berkembang yang belum terselesaikan sampai sekarang. Salah satunya sampah organik yang jumlahnya bisa mencapai $80 \%$ dari total sampah, yang biasanya hanya dilihat sebagai barang sisa tanpa nilai ekonomi sehingga perlu dilakukan kegiatan pengomposan agar tidak hanya dibuang dan ditimbun di TPA (Tempat Pembuangan Akhir) yang dapat meningkatkan penyebaran vektor penyakit dan produksi gas rumah kaca (1). Pengomposan (composting) merupakan salah satu upaya dalam pengelolaan sampah organik dan dapat mengurangi volume sampah hingga 50\% dan mengonsumsi $50 \%$ materi organik pada sampah dalam berat kering serta melepaskan gas $\mathrm{CO}_{2}$ dan air. Dalam proses 


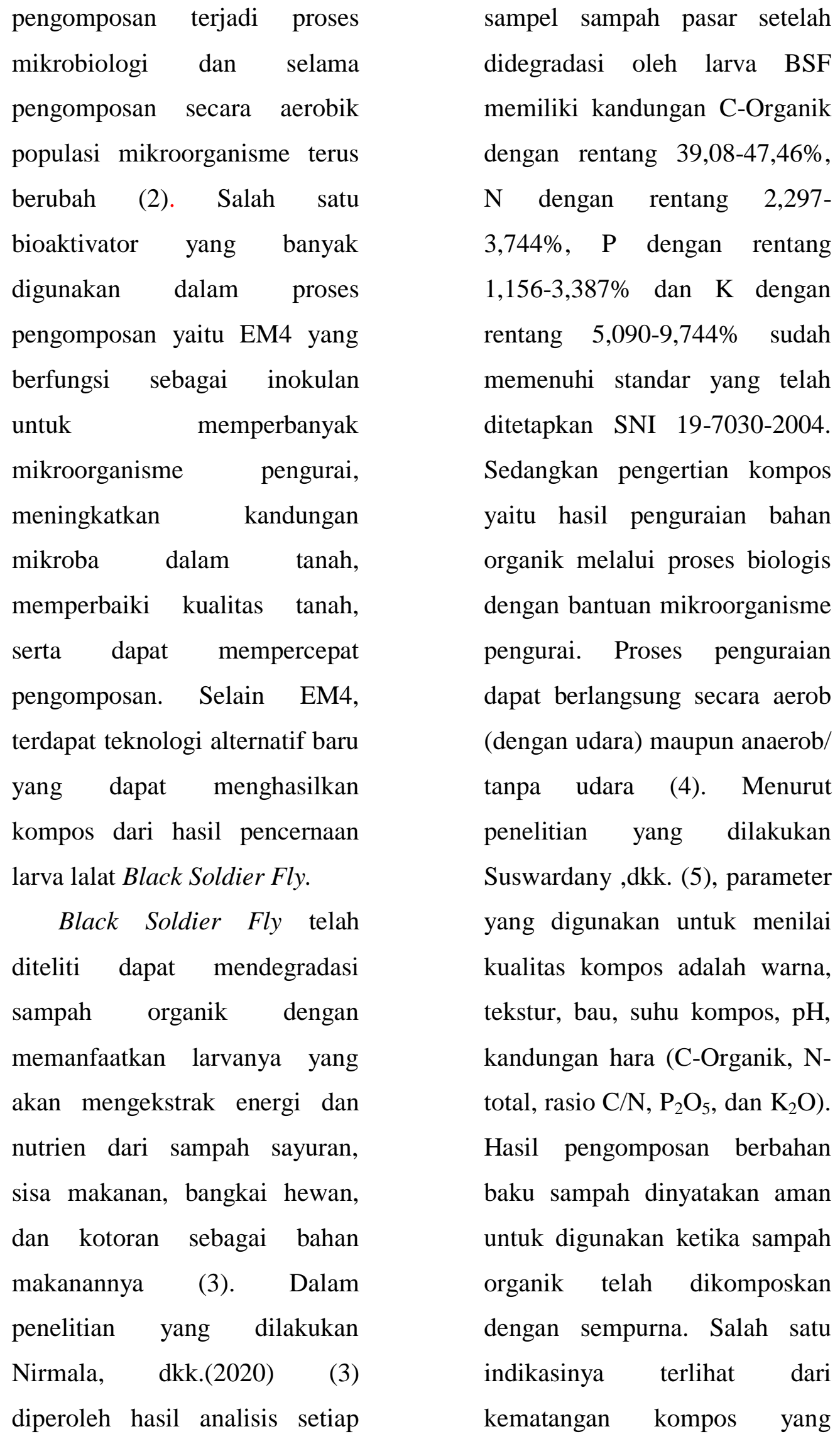


meliputi karakteristik fisik (bau, warna, dan tekstur yang menyerupai tanah, penyusutan berat mencapai $60 \%$, pH netral, suhu stabil), perubahan kandungan hara, dan tingkat fitotoksitas rendah (5).

Tujuan dari penelitian ini yaitu untuk mengetahui perbedaan kualitas kompos EM4 dengan kompos Black Soldier Fly sedangkan tujuan khusus dari penelitian ini adalah : (a) Untuk mengetahui kualitas kompos EM4, (b) Untuk mengetahui kualitas kompos Black Soldier Fly, (c) Menganalisis perbedaan kualitas kompos EM4 dan kompos Black Soldier Fly.

\section{METODE PENELITIAN}

Dalam penelitian ini, jenis penelitian yang dipakai adalah penelitian eksperimental dengan jenis penelitian preexperimental design dengan desain one-shot case study, serta uji independent $t$ test untuk menganalisis perbedaan kualitas kompos (6). Sampel yang digunakan yaitu 8 sampel kompos Black Soldier Fly dan delapan data sekunder untuk kompos EM4. Penggunaan data sekunder EM4 dalam analisis perbedaan kualitas kompos EM4 dengan kompos Black Soldier Fly layak untuk dibandingkan apabila sudah dilakukan uji normalitas data dan memenuhi syarat data berdistribusi normal sehingga dapat dilanjutkan ke tahap analisis bivariat menggunakan uji beda untuk mengetahui ada atau tidak adanya perbedaan. Penelitian ini dilakukan di desa Buduk khususnya di TPS Desa Buduk yang terdapat budidaya Larva Black Soldier Fly dengan pengurusan ijin dimulai tanggal 12 September 2019. Proses pengomposan meggunakan larva Black Soldier Fly dilakukan selama 20 hari. Volume sampah yang diberikan sebanyak $2 \mathrm{~kg}$ sampah sayuran dan buahbuahan per hari untuk setiap 0,5 $\mathrm{kg}$ larva. Adapun waktu penelitian akan dimulai bulan Februari hingga Maret 2020.

Teknik pengumpulan data yang dilakukan dalam penelitian 
ini berupa (a) Data Primer adalah : data hasil pemeriksaan kualitas kompos Black Soldier Fly yang telah diperiksa di laboratorium, (b) Data Sekunder : data yang diperoleh dengan mengutip data kualitas kompos EM4 dari delapan penilitian sebelumnya. Untuk memudahkan peneliti dalam pengolahan data, maka data yang telah terkumpul dilakukan uji normalitas data menggunakan shapiro wilk untuk mengetahui data berdistriusi normal atau tidak kemudian dianalisis secara univariat utuk mengetahui ratarata hasil yang didapat. Kemudian dilakukan analisis bivariat menggunakan uji beda independent $t$ test dan disajikan dalam bentuk tabel. Kualitas kimia yang diukur dari kedua kompos tersebut terdiri dari NTotal, $\mathrm{P}_{2} \mathrm{O}_{5}$ dan $\mathrm{K}_{2} \mathrm{O}$ yang telah memiliki standar menurut SNI 19-7030-2004 (7) tentang Spesifikasi Kompos dari Sampah Organik Domestik yaitu $\mathrm{N}$ total minimum 0,$4 ; \mathrm{P}_{2} \mathrm{O}_{5}$ min 0,1 dan $\mathrm{K}_{2} \mathrm{O} \min 0,2$.

\section{HASIL DAN PEMBAHASAN}

Berdasarkan data primer dan data sekunder yang telah dikumpulkan dan dilakukan uji normalitas, diperoleh data beristribusi normal dengan hasil kandungan N,P,K kompos EM4 dan kompos larva Black Soldier Fly pada tabel 1 sebagai berikut. 
Tabel 1

Perbandingan Kualitas Kompos EM4 dengan Kompos Black Soldier Fly

SNI 19-7030-2004 ( $N \min 0,4 \% ; P_{2} O_{5} \min 0,1 \% ; K_{2} O \min 0,2 \%$ )

\begin{tabular}{cccccccc}
\hline Perlakuan & $\mathbf{N}$ & $\mathbf{P}_{\mathbf{2}} \mathbf{O}_{\mathbf{5}}$ & $\mathbf{K}_{\mathbf{2}} \mathbf{O}$ & $\mathbf{B S F}$ & $\mathbf{N}$ & $\mathbf{P}_{\mathbf{2}} \mathbf{O}_{\mathbf{5}}$ & $\mathbf{K}_{\mathbf{2}} \mathbf{O}$ \\
\hline EM4 & $1,75 \%$ & $0,26 \%$ & $2,11 \%$ & Sampel 1 & $1,85 \%$ & $0,32 \%$ & $4,40 \%$ \\
EM4 & $0,86 \%$ & $0,68 \%$ & $0,48 \%$ & Sampel 2 & $2,46 \%$ & $1,14 \%$ & $3,53 \%$ \\
EM4 & $1.92 \%$ & $0.151 \%$ & $0.27 \%$ & Sampel 3 & $2,00 \%$ & $0,81 \%$ & $2,75 \%$ \\
EM4 & $1,29 \%$ & $0,13 \%$ & $0,07 \%$ & Sampel 4 & $2,15 \%$ & $0,75 \%$ & $3,43 \%$ \\
EM4 & $2,80 \%$ & $1,16 \%$ & $0,64 \%$ & Sampel 5 & $1,72 \%$ & $1,23 \%$ & $4,13 \%$ \\
EM4 & $2,19 \%$ & $0,69 \%$ & $1,67 \%$ & Sampel 6 & $0,83 \%$ & $0,75 \%$ & $2,67 \%$ \\
EM4 & $1,84 \%$ & $0,08 \%$ & $1,70 \%$ & Sampel 7 & $1,37 \%$ & $1,25 \%$ & $2,85 \%$ \\
EM4 & $1,15 \%$ & $2,43 \%$ & $0,53 \%$ & Sampel 8 & $0,92 \%$ & $1,74 \%$ & $4,27 \%$ \\
\hline
\end{tabular}

Berdasarkan hasil uji statistik untuk mengetahui perbedaan kandungan kompos, didapatkan hasil sebagai berikut.

Tabel 2

Hasil Uji Kualitas Kompos EM4 dengan Kompos Black Soldier Fly

\begin{tabular}{ccccc}
\hline $\begin{array}{c}\text { Parameter } \\
\text { Kualitas } \\
\text { Kompos }\end{array}$ & $\begin{array}{c}\text { Rata-rata } \\
\text { EM4 }\end{array}$ & $\begin{array}{c}\text { Rata-rata } \\
\text { BSF }\end{array}$ & Signifikansi & t hitung \\
\hline $\mathbf{N}$ & $1.7250 \%$ & $1,663 \%$ & 0,838 & 0,208 \\
$\mathbf{P}_{\mathbf{2}} \mathbf{O}_{\mathbf{5}}$ & $0,6975 \%$ & $0,9988 \%$ & 0,362 & 0,943 \\
$\mathbf{K}_{\mathbf{2}} \mathbf{O}$ & $0,9338 \%$ & $3,5038 \%$ & 0,000 & 6,961 \\
\hline
\end{tabular}

Menunjuk hasil pada tabel 2 diperoleh hasil kompos EM4 dan Black Soldier Fly tidak memiliki perbedaan pada kandungan nitrogen dan fosfor tetapi memiliki perbedaan pada kandungan kalium. Kandungan nitrogen yang tidak berbeda disebabkan oleh kompos EM4 menggunakan mikroorganisme untuk mendekomposisi sampah organik sedangkan kompos Black Soldier Fly menggunakan Black Soldier Fly itu sendiri sebagai 


\begin{abstract}
dekomposter
untuk

mendekomposisi sampah organik.

Dalam pengertian lain, kandungan

$\mathrm{N}$ dalam kompos yang tidak berbeda disebabkan karena sedikitnya nitrogen yang terlepas dikarenakan proses dekomposisi oleh mikroorganisme (mikroorganisme dari larutan aktivator EM4 dan Black Soldier Fly) sehingga nitrogen terperangkap di dalam pori-pori tumpukan kompos yang sangat kecil. Sedangkan nilai fosfor yang tidak berbeda pada kompos EM4 dan kompos BSF dapat dipengaruhi oleh tingginya kadar nitrogen pada kompos akibat adanya kotoran hewan sehingga semakin tinggi kadar nitrogen yang terkandung maka multiplikasi mikroorganisme pada EM4 maupun larva BSF akan merombak fosfor sehingga terjadi kenaikan kandungan fosfor pada kompos.
\end{abstract}

Kandungan kalium yang berbeda pada kompos EM4 dan kompos BSF disebabkan oleh sampah organik berupa sayuran hijau dan buah-buahan yang dijadikan bahan dasar kompos Black Soldier Fly lebih banyak dengan pemberian sampah sebanyak $2 \mathrm{~kg}$ selama 20 hari pengomposan. Hal ini menyebabkan nilai rata-rata kandungan kalium pada kompos BSF lebih tinggi dan lebih baik daripada kompos EM4 karena kompos BSF lebih banyak mengandung sampah sayuran dan buah-buahan tanpa campuran lainnya. Sedangkan bioaktivator EM4 menggunakan jumlah volume sampah yang tetap dan dicampur kotoran hewan maupun mol limbah organik kemudian didiamkan selama 2-3 minggu tanpa penambahan sampah kembali yang selanjutnya dilakukan pengukuran nilai $\mathrm{pH}$, kelembaban, dan suhu pada kompos EM4. Dalam buku Penggunaan Larva (Maggot) Black Soldier Fly dalam Pengolahan Limbah Organik (8) menjelaskan bahwa hasil analisis kandungan sampah organik larva Black Soldier Fly yang dibedakan melalui umur larva diperoleh hasil bahwa kompos yang berumur 15 hari memiliki kandungan $\mathrm{N}$ 
$1,82 \%$; P $1,43 \%$ dan $\mathrm{K} 5,44 \%$ sedangkan kompos dengan umur 30 hari memiliki kandungan $\mathrm{N}$ $3,60 \%$; P $0,14 \%$ dan K 7,88\%. Selain itu juga penelitian Nursaid,dkk. (9) dari Universitas Indonesia melakukan pengukuran parameter $\mathrm{N}, \mathrm{P}, \mathrm{K}$ pada hasil kompos dari proses biokonversi sampah buah dengan larva Black Soldier Fly (Hermetia illucens) dengan proses feeding secara kontinu memiliki hasil cukup baik, dengan hasil parameter $\mathrm{N}, \mathrm{P}$ dan K yang memenehui SNI 197030-2004 (BSN 2004) di semua reactor dengan nilai sebesar $\mathrm{N}$ 0,54\%; P 0,85\% dan K 1,02\%. Selain menghasilkan kompos, Black Soldier Fly yang telah menjadi prepupa juga dapat menjadi salah satu alternatif pakan ternak karena memiliki kandungan protein yang cukup tinggi. Pemanfaatan EM4 dan larva Black Soldier Fly dalam pengomposan sampah organik merupakan solusi alternatif dalam mengurangi populasi sampah organik yang semakin meningkat sehingga diharapkan masyarakat sadar dan lebih peduli terhadap sampah atau limbah organik disekitarnya dengan memanfaatkan sampah menjadi kompos yang memiliki nilai ekonomis dan membantu dalam penyuburan tanah maupun tanaman (10).

\section{SIMPULAN DAN SARAN}

Berdasarkan hasil penelitian yang telah dilakukan, dapat disimpulkan beberapa hal sebagai berikut.

a. Rata-rata dari sampel kompos Black Soldier Fly yang diperiksa yaitu kandungan $\mathrm{N}(1,6625 \%)$; $\mathrm{P}_{2} \mathrm{O}_{5} \quad(0,9988 \%) ; \quad \mathrm{K}_{2} \mathrm{O}$ $(3,5038 \%)$. Hasil tersebut sudah memenuhi standar kualitas kompos menurut SNI 19-7030-2004.

b. Rata-rata kandungan kualitas kompos EM4 didapat yaitu, nilai $\mathrm{N} \quad(1,7250 \%) ; \quad \mathrm{P}_{2} \mathrm{O}_{5}$ $(0,6975 \%) ; \quad \mathrm{K}_{2} \mathrm{O}(0,9338 \%)$. Hasil rata-rata tersebut sudah memenuhi standar kualitas kompos menurut SNI 19-70302004.

c. Berdasarkan hasil uji independent $t$ test didapatkan 


\begin{abstract}
hasil kandungan $\mathrm{N}$ dan $\mathrm{P}$ tidak memiliki perbedaan sedangkan kandungan $\mathrm{K} \quad$ memiliki perbedaan. Nilai N,P,K kedua kompos sudah memenuhi standar kualitas kompos yang telah ditetapkan dengan kandungan $\mathrm{K}$ pada kompos BSF lebih baik daripada kompos EM4.
\end{abstract}

Adapun saran penulis yang dapat disampaikan sebagi berikut :

(1) Melakukan analisis lanjutan terhadap kualitas fisik dan kimia pada kompos Black Soldier Fly yang tidak dilakukan oleh peneliti seperti kadar air, $\mathrm{C} / \mathrm{N}$ rasio, C-organik, suhu, pH, dan kelembaban.

(2) Penelitian lebih lanjut menggunakan bahan baku yang lebih variatif lagi, misalkan sampah organik dari rumah tangga yang komposisinya lebih kompleks lagi sehingga dapat mengurangi penumpukan sampah organik di lingkungan sekitar maupun TPA.

(3) Melakukan percobaan dan pengukuran dengan kompos Black Soldier Fly secara langsung terhadap tumbuhan ataupun tanah

\section{DAFTAR PUSTAKA}

1. Diener S. 2010. Valorisation Of Organic Solid Waste Using The Black Soldier Fly, Hermetia Illucens L., In Low And Middle-Income Countries.

2. Samekto R. Pupuk Kompos. 1st ed. Yogyakarta: PT Ciitra Aji Parama; 2006. 44 p.

3. Nirmala W, Purwanigrum P, Indrawati D. Pengaruh

$$
\begin{aligned}
& \text { Komposisi Sampah Pasar } \\
& \text { Terhadap Kualitas Kompos } \\
& \text { Organik dengan Metode Larva } \\
& \text { Black Soldier Fly (BSF). } \\
& \text { 2020;1-5. } \\
& \text { 4. Yulianto AB, dkk. Buku } \\
& \text { Pedoman Pengolahan Sampah } \\
& \text { Terpadu: Konversi Sampah } \\
& \text { Pasar Menjadi Kompos }
\end{aligned}
$$


Berkualitas Tinggi.

Bhinekawati R, Joko F, Rima

L, Wiranto B, editors. Jakarta:

Yayasan Danamon Peduli;

$2009.59 \mathrm{p}$.

5. Suswardany DL, Kusumawati

Y. Peran Efective

Microorganism-4 (EM-4)

Dalam Meningkatkan Kualitas

Kimia Kompos Ampas Tahu.

J Penelit Sains Teknol.

2006;7(2):141-9.

6. Sugiyono. Metode Penelitian

Kuantitatif, Kualitatif, dan

R\&D. Bandung: Alfabeta; 2017.

7. SNI 19-7030-2004.

Spesifikasi Kompos Dari

Sampah Organik Domestik.

2004;(Cd):7030.

8. Yuwono AS, Mentari PD.

Penggunaan Larva (Maggot)
Black Soldier Fly ( BSF )

Dalam PengoLahan Limbah

Organik. 1st ed. Bogor,

Indonesia: SEAMEO

BIOTROP Southeast Asian

Regional Centre for Tropical

Biology; 2018.

9. Nursaid AA, Yuriandala Y, Maziya FB. Analisis Laju

Penguraian dan Hasil Kompos

Pada Pengolahan Sampah

buah Dengan Larva Black

Soldier Fly ( Hermetia

Illucens ). 2019;(2004):1-9.

10. Dortmans B, Diener S,

Verstappen B, Zurbrugg C.

Proses Pengolahan Sampah

Organik dengan Black Soldier

Fly ( BSF ). Donahue P,

editor. Switzerland:

Deparment od Sanitation,

Water and Solid Waste for

Development (Sandec); 2017. 